\title{
Wpływ lokalizacji inwestycji mieszkaniowych na prawidłowy rozwój Krakowa ${ }^{1}$
}

\section{The influence of the location of housing} investments on the development of Krakow ${ }^{1}$

\begin{abstract}
Streszczenie
Jednym z głównych wyzwań współczesnych miast jest dostępność mieszkań. Czynniki ekonomiczne kształtujące sytuację na rynku nieruchomości znacząco wpływają na dobór ich lokalizacji. Jako że jest to wybór deweloperów kierujących się swoim własnym zyskiem, nie zawsze jest on korzystny dla miasta. Niniejsza praca wyróżnia trzy podstawowe zasady wyboru działek, które niosą za sobą ryzyko zaburzeń dla prawidłowego rozwoju miasta, oraz dokonuje ich prezentacji na podstawie wybranych przykładów.
\end{abstract}

Słowa kluczowe: Kraków, urbanistyka, suburbanizacja, ład przestrzenny, zespoły mieszkaniowe, rozwój, planowanie przestrzenne, miasto

\begin{abstract}
One of the primary challenges for modern cities is the availability of homes. Today, the property market is very important because it affect for localization new housing estates. Investors choose locations, guided by yourself profit. Unfortunately sometimes their choice is not the best for the development of city and can create new problems for the city. In this publication are three main kind of locations negative for city development described with a few examples.
\end{abstract}

Keywords: Krakow, urbanism, suburbanisation, housing estate, urban planning, development, city 


\section{OGÓLNA CHARAKTERYSTYKA SYTUACJI MIESZKANIOWEJ W KRAKOWIE}

Kraków podobnie jak niemal wszystkie współczesne metropolie zmaga się z licznymi wyzwaniami, przed którymi staje. Jednymi z jego podstawowych problemów są dzisiaj wysokie ceny mieszkań oraz niska jakość wielu nowo powstających zespołów mieszkaniowych. Wpływa to bezpośrednio na dostępność mieszkań, jakość życia mieszkańców oraz funkcjonowanie całego miasta.

Znaczna część współczesnych realizacji mieszkaniowych posiada wiele istotnych niedociągnięć, o których wielokrotnie donosiły lokalne media, jak choćby w przypadku Ruczaju, czy os. Avia. Do najczęściej spotykanych z całą pewnością można zaliczyć niedobór terenów zielonych, miejsc postojowych, placówek oświatowych, grodzenie osiedli, niewielkie odległości między budynkami, niskie walory architektoniczno-przestrzenne i wiele innych. Wszystkie te wady wynikają wprost z tzw. wyciskania PUM-u - powierzchni użytkowej mieszkań, co wiąże się z bezpośrednim zyskiem dla inwestora. Nie należy się spodziewać, że podmiot prywatny, który ponosi wszelkie potencjalne ryzyko związane z daną inwestycją, będzie ograniczać swój zysk. Niemniej należy poznawać i definiować negatywne zjawiska urbanistyczne i walczyć z nimi, gdyż ich skutki miasto będzie odczuwać przez dziesięciolecia, jak nie setki lat.

\section{ANALIZA SYTUACJI NA RYNKU NIERUCHOMOŚCI}

Pomimo swoich wad oraz rosnącej świadomości społeczeństwa, nowe mieszkania wciąż znajdują nabywców. Wynika to bowiem z faktu, że w dalszym ciągu jednym z podstawowych kryteriów wyboru mieszkania jest jego cena, której średnia wartość wynosiła 7000 zł $/ \mathrm{m}^{2}$ w 2017 r. ${ }^{2}$ Przy średniej wielkości nowo oddanych do użytku mieszkań $\left(56,1 \mathrm{~m}^{2}\right)^{3}$ daje to średnią cenę lokalu wynoszącą ok. 392700 zł. Uwzględniając wysokość średniego wynagrodzenia w 2017 r. (4 966,20 zł/mies. brutto) , wyliczyć można, że stanowi to równowartość 111,35 miesięcznych pensji netto - 9,3 lat.

Niestety dalsza analiza rynku nieruchomości nie napawa optymizmem. W wyniku trwającego od lat boomu inwestycyjnego deweloperzy znacząco wyczerpali ilość dostępnych działek pod nowe realizacje. Spowodowało to drastyczny, wynoszący w zależności od dzielnicy $15-25 \%{ }^{5}$ wzrost cen działek pod zabudowę mieszkaniową. Ponadto ograniczona dostępność gruntów inwestycyjnych odbiła się na znaczącej redukcji liczby nowych inwestycji mieszkaniowych, z ok. 210 w I połowie 2016 r. do zaledwie 143 pod koniec 2017 r. - spadek o niemal $30 \%{ }^{6}$. To z kolei wpływa na wzrost cen mieszkań, których wartość wzrosła z niecałych $6000 \mathrm{zł} / \mathrm{m}^{2}$ na przełomie 2015 i 2016 r. ${ }^{7}$ do 7000 zł $/ \mathrm{m}^{2}$ w 2017 r. - 17\% wzrostu.

Cały czas mowa tu o uśrednionych wartościach dla całego miasta, dlatego też należy zwrócić uwagę na wpływ lokalizacji na ceny mieszkań. Oczywiście wartość danego lokalu 
jest wypadkową wielu czynników, nie tylko tych związanych z lokalizacją. Niemniej analiza uśrednionych cen mieszkań w poszczególnych dzielnicach pozwala na zaobserwowanie dwóch podstawowych zależności. Pierwszą, dość oczywistą, jest odległość od centrum miasta. W myśl tej zasady najdroższa, z wynikiem 14200 zł/m², jest dzielnica I - Stare Miasto. Następnie wraz ze wzrostem odległości od centrum ceny te spadają do poziomu $5200 \mathrm{zł} / \mathrm{m}^{2}$ w znajdujących się na granicy miasta Swoszowicach ${ }^{9}$. Ze względu na postrzeganie poszczególnych rejonów miasta jako mniej lub bardziej atrakcyjnych w opisanej powyżej zasadzie pojawiają się pewne anomalie. Wynika to m.in. z faktu postrzegania dzielnicy VII - Zwierzyniec - jako prestiżowej dzielnicy willowej oraz negatywnego spojrzenia wielu potencjalnych nabywców na tzw. dzielnice nowohuckie.

Pomimo iż aktualna sytuacja na rynku nieruchomości znacząco ogranicza dostępność i jakość nowo budowanych mieszkań w Krakowie, nie należy spodziewać się nagłego spadku zainteresowania nowymi inwestycjami. Własne schronienie, dom to jedna z podstawowych potrzeb ludzkich, którą należy zaspokoić dla prawidłowego funkcjonowania człowieka i całego społeczeństwa. Z tego względu zdecydowanie bardziej prawdopodobne jest obniżenie oczekiwań i wymagań nabywców, stosownie do ich możliwości finansowych. W zależności od indywidualnych preferencji może to być wybór mniejszego mieszkania, o niższym standardzie, lub wybór mniej atrakcyjnej lokalizacji. To w połączeniu z deficytem wolnych gruntów budowlanych prowadzi do poszukiwania przez deweloperów wszelkich dostępnych działek pod nowe inwestycje. Niestety takie podejście, często polegające na „budowaniu, gdzie się tylko da", sprawia, że miasto zaczyna rozwijać się w sposób niekontrolowany. Bowiem o ile wybór mniejszego lokalu obniża jakość życia konkretnych mieszkańców, wpływając na pogorszenie oceny miasta pod względem jakości życia, to ma on jednak ograniczony wpływ na ład przestrzenny i jego funkcjonowanie. Natomiast oddziaływanie lokalizacji jest już zdecydowanie silniejsze i łatwiej dostrzegalne. Mówiąc o wpływie doboru działek pod inwestycje mieszkaniowe na prawidłowy rozwój całego miasta, można zdefiniować kilka podstawowych typów tych lokalizacji obserwowanych na przykładzie Krakowa.

\section{CHAOTYCZNE DOGĘSZCZANIE ZABUDOWY MIEJSKIEJ}

Pierwszym, zupełnie naturalnym działaniem jest poszukiwanie mieszkań zapewniających jak najkorzystniejszy stosunek w relacji między ceną a lokalizacją. Najlepszym tego przykładem jest dzielnica $V$ - Krowodrza. Dzięki niemal bezpośredniemu sąsiedztwu z centrum miasta i jej dobrym powiązaniom przestrzennym, komunikacyjnym i funkcjonalnym stanowi bardzo atrakcyjną propozycję. Jednocześnie jako że jest już lekko oddalona od centrum, ceny lokali w tej dzielnicy są akceptowalne dla większej liczby nabywców niż w Starym Mieście. Przekłada się to na duże zainteresowanie tym obszarem miasta i liczbę prowadzonych inwestycji przez deweloperów. Co ciekawe, pomimo opisanego wcześniej znaczącego spadku 
liczby prowadzonych inwestycji mieszkaniowych w Krakowie oraz stosunkowo gęstej zabudowy i niewielkiej liczby wolnych działek, zaobserwowano tutaj największą liczbę prowadzonych inwestycji w 2017 r. ${ }^{10}$ Oczywiście nie pozostaje to obojętne dla miasta, bowiem prowadzi to do chaotycznej zabudowy terenu. Jako przykład tego typu sytuacji może posłużyć zainteresowanie deweloperów wolnymi działkami wewnątrz zielonego podwórka między ul. Bytomską a ul. Racławicką ${ }^{11}$. Zabudowa tego terenu doprowadziłaby do degradacji jakości przestrzeni poprzez nadmierne zagęszczenie, likwidację terenów zielonych oraz generowanie dużego ruchu samochodowego na jednokierunkowej drodze dojazdowej.

Ponadto odnotowano próby zabudowy terenów przyległych do parku Młynówka Królewska, stanowiącego jeden z nielicznych ogólnodostępnych terenów zielonych w tej części miasta. Najlepszym przykładem jest realizacja budynku przy al. Kijowskiej 40 . O ile dla jego mieszkańców jest to wręcz wymarzone miejsce, w centrum, na działce otoczonej zielenią, to dla miasta jako całości jest to niekorzystna sytuacja. Realizacja ta odstaje od pozostałej zabudowy, stanowi swojego rodzaju „wyspę”, jednocześnie mocno ogranicza dostępność terenów zielonych. Znajduje się także ona na osi wyznaczonej przez kościół położony po przeciwnej stronie ulicy. Brak zabudowy w tym miejscu mógłby pozwolić na powstanie atrakcyjnej przestrzeni publicznej połączonej z terenami zielonymi i opartej na osi kompozycyjnej wyznaczonej przez lokalną dominantę, jaką niewątpliwie jest ta świątynia.

Kolejne przykłady zabudowy tego parku opisano niedawno w lokalnej prasie. Urzędnicy miejscy wydali pozwolenie na budowę budynku mieszkalnego na działce przy ul. Zarzecze, w bezpośrednim sąsiedztwie Młynówki Królewskiej ${ }^{12}$. Co istotne, działka ta stanowi zielony łącznik między ul. Zarzecze a parkiem. W jej granicach znajduje się także niewielkie skupisko drzew. Realizacja tej inwestycji będzie się wiązać z ich wycinką, a także ze zwężeniem zielonego pasa łączącego park z ulicą i okolicznymi zabudowaniami. W dodatku, według doniesień medialnych, planowana inwestycja ma być niemal dwukrotnie wyższa od sąsiadującej z nią istniejącej zabudowy, co dodatkowo wzmacnia jej negatywne oddziaływanie na okolicę.

\section{SUBURBANIZACJA}

\subsection{OPIS I GŁÓWNE PRZYCZYNY SUBURBANIZACJI}

Innym negatywnym zjawiskiem wynikającym z niekorzystnego wyboru lokalizacji inwestycji mieszkaniowych jest suburbanizacja, polegająca na migracji ludności z miasta na tereny przedmiejskie. Jest to powszechnie występująca tendencja w wielu różnych metropoliach, wynika bowiem z pragnienia ludzi do posiadania własnego domu z ogrodem, chęci ucieczki z miasta w poszukiwaniu ciszy i spokoju poza nim, przy jednoczesnym oparciu swoich aktywności o ośrodek miejski. Pomimo iż samo zjawisko jest dobrze znane i opisane, 
to każde miasto posiada odmienne uwarunkowania przestrzenne, komunikacyjne, środowiskowe, prawne, ekonomiczne i społeczne. Z tego względu sytuację tę należy rozważyć dla tego konkretnego miasta.

Niewątpliwy wpływ na postępowanie suburbanizcji w tym przypadku ma opisywana wcześniej relacja między odległością od centrum a ceną. Potwierdza to analiza cen nieruchomości w Krakowie, gdzie średnia cena mieszkań w najtańszych Swoszowicach wynosiła 5200 zł $/ \mathrm{m}^{2}$ w 2017 r., natomiast w żadnej z gmin powiatu krakowskiego średnia wartość domu deweloperskiego za $1 \mathrm{~m}^{2}$ nie przekroczyła progu $5000 \mathrm{zł}^{13}$. Atrakcyjne ceny w połączeniu z większą dostępnością wolnych działek budowlanych generują coraz większe zainteresowanie deweloperów inwestowaniem w gminach sąsiadujących z Krakowem.

\subsection{ROZPROSZENIE ZABUDOWY NA OBSZARZE PRZEDMIEŚĆ}

Niestety temu trendowi sprzyja nastawienie władz gmin, które w całej Polsce, licząc na pozyskanie nowych mieszkańców, a tym samym zwiększone wpływy na lokalne budżety, w ustanawianych przez siebie miejscowych planach zagospodarowania przestrzennego wyznaczają dużą część swoich terenów pod zabudowę mieszkaniową. Dobrze obrazuje to fakt, iż w skali całego kraju na terenach, które te plany obejmują, mogłoby zamieszkać nawet $76 \mathrm{mln}$ osób ${ }^{14}$. Wielkość problemu podkreśla to, że w naszym kraju jedynie ok. 30\% powierzchni jest pokryte planami miejscowymi ${ }^{15}$. Ten stan rzeczy znajduje odzwierciedlenie także na przykładzie przypadkowo wybranej podkrakowskiej wsi - Michałowice. Pomimo iż jej gęstość zaludnienia jest o wiele niższa od określanej przez Instytut Geografii i Przestrzennego Zagospodarowania PAN chłonności demograficznej na poziomie 40 os./ha ${ }^{16}$ i wynosi zaledwie $2,8 \mathrm{os} . / \mathrm{ha}^{17}$, to już pobieżna analiza załącznika graficznego do obowiązującego planu miejscowego pokazuje zdominowanie obszaru wsi przez tereny przeznaczone pod zabudowę mieszkaniową lub ją dopuszczające. Na niemal wszystkich działkach przyległych do dróg zezwolono na wznoszenie domów mieszkalnych. Jedynie tereny od nich oddalone, a także korytarz wyznaczony przez Dłubniański Park Krajobrazowy, są wolne od zabudowy.

Prowadzi to do rozciągnięcia zabudowy wzdłuż dróg, zamiast do jej koncentracji w określonych obszarach. Znaczne rozproszenie zabudowy generuje wzrost kosztów funkcjonowania gminy oraz zaburza jej ład przestrzenny i krajobrazowy. Porównując polskie i niemieckie wsie i miasteczka, można dostrzec, że u naszych sąsiadów zdecydowanie częściej znajdziemy chodniki wzdłuż dróg, oświetlenie uliczne, place zabaw, przystanki komunikacyjne itd. Wynika to z faktu, że w Niemczech wznoszona zabudowa jest gęsta i zwarta, nie ma przyzwolenia na jej rozpraszanie, co pozwala na redukcję kosztów inwestycji publicznych. Niestety w okolicach Krakowa obserwujemy tendencje odwrotne do tych pozytywnych wzorców, co skutkuje licznymi problemami zarówno dla tych gmin, ich mieszkańców, jak i dla Krakowa. 


\subsection{GŁÓWNE PROBLEMY WYNIKAJĄCE Z SUBURBANIZACJI I ROZPROSZENIA ZABUDOWY}

Silne rozproszenie zabudowy mieszkaniowej powoduje powstawanie obszarów wykluczonych komunikacyjnie, ze względu na nierentowność potencjalnych linii komunikacyjnych. W takiej sytuacji dużym wyzwaniem jest stworzenie sieci szybkiego i wysokowydajnego transportu, takiego jak kolej metropolitalna, który obsługiwałby duże potoki pasażerskie. Naturalnym wyborem środka transportu pozostaje więc samochód prywatny, co w połączeniu z wydłużonymi trasami komunikacyjnymi (w porównaniu do zabudowy mieszkaniowej wewnątrz miasta) generuje kolejne problemy, takie jak m.in.: niewydolność infrastruktury drogowej i parkingowej, zanieczyszczenia, hałas, zwiększone ryzyko kolizji i wypadków czy zdominowanie przestrzeni przez samochody.

Kolejnym problemem, na który ma wpływ suburbanizacja i rozproszenie zabudowy przedmieść, jest zanieczyszczenie powietrza. Jedynie w Krakowie obowiązuje zakaz stosowania paliw stałych do ogrzewania mieszkań, co dozwolone jest w gminach ościennych. W dodatku znaczna część z nich okazuje niemal całkowity brak zainteresowania tą kwestią ${ }^{18}$. W takiej sytuacji ciężko oczekiwać, że sami mieszkańcy będą decydować się na zmianę swoich przyzwyczajeń w tym względzie, mając na uwadze deficyt alternatywnych możliwości ogrzewania swoich domów. Odnawialne źródła energii wymagają bardzo kosztownych inwestycji, które zniechęcają ludzi, energia elektryczna jest nieopłacalna ekonomicznie. W tej sytuacji podstawową alternatywą dla paliw stałych są piecyki gazowe. Niestety ze względu na znaczne rozproszenie zabudowy, stworzenie gazociągów do obsługi tych domów w wielu miejscach jest nieopłacalne. Niestety ma to tym większe znaczenie dla Krakowa, że leży on na samym dnie doliny, więc spływają do niego zanieczyszczenia z okalających miejscowości.

\section{WYSPOWE OSADNICTWO WEWNĄTRZ MIASTA}

\subsection{DEFINICJA, OPIS I KLASYFIKACJA WYSPOWEGO OSADNICTWA WEWNĄTRZ MIASTA}

Kolejnym interesującym zjawiskiem, związanym z poszukiwaniem przez inwestorów terenów pod budowę zespołów mieszkaniowych, które obserwujemy w Krakowie, jest „wyspowe osadnictwo wewnątrz miasta". Polega ono na powstawaniu jedno- i wielorodzinnych enklaw mieszkaniowych w granicach administracyjnych miasta, lecz nieposiadających wyraźnych powiązań przestrzennych, funkcjonalnych i komunikacyjnych z innymi obszarami. Zazwyczaj wznoszone są w lokalizacjach charakteryzujących się niskimi cenami działek, co wynika z ich stosunkowo małej atrakcyjności. Otoczone terenami o zupełnie innej, często wręcz kolizyjnej funkcji, nie posiadają odpowiedniej infrastruktury miejskiej oraz znajdują 
się zazwyczaj z dala od centrum miasta. Tworzą one coś na wzór miasta w mieście. Jednocześnie ich monofunkcjonalny charakter nie zapewnia im samodzielnego funkcjonowania i wymusza codzienne podróże mieszkańców w celu zapewnienia sobie dostępu nawet do podstawowych potrzeb.

Ze względu na funkcje terenów sąsiadujących z tymi zespołami możemy wyróżnić dwa podstawowe rodzaje tego typu zabudowy. Pierwszy z nich lokalizowany jest pośród terenów przemysłowo-magazynowych. Należy przy tym zwrócić uwagę na fakt, że takie inwestycje nie stanowią rewitalizacji terenów poprzemysłowych, różnica między tymi dwoma zjawiskami jest znacząca. Celem wyspowego osadnictwa jest znalezienie tanich gruntów budowlanych, lokalizowanych m.in. w sąsiedztwie funkcjonujących zakładów przemysłowych. Dopiero z czasem może to prowadzić do wypierania przemysłu ze względu na chęć zysku ze sprzedaży kolejnych mieszkań lub uciążliwość owych zakładów. Jednocześnie zabudowania w takich rejonach nie stanowią popularnych w XIX wieku osiedli robotniczych. Powstają jako niezależne od sąsiadującego z nimi przemysłu inwestycje, które chociaż oczywiście mogą zapewniać zakwaterowanie pracownikom pobliskich zakładów, to nie jest to ich celem. Jako przykłady tego typu osiedli mogą posłużyć np.: os. Złocień, zabudowania w okolicy ul. Sołtysowskiej czy ul. Rydlówka.

Drugi typ znajduje się w otoczeniu zdecydowanie bardziej przyjaznym, lokalizowany jest na terenach o charakterze przedmiejskim lub nawet wiejskim. Otoczony jest licznymi terenami zielonymi, w tym nieraz polami rolnymi, a także rzadką zabudową jednorodzinną. Od samodzielnej wsi lub miasteczek różni je przede wszystkim ulokowanie w granicach administracyjnych miasta, pełne uzależnienie funkcjonalne, społeczne i kulturalne od niego, a także nieraz skala i intensywność zabudowy. Ciekawymi przykładami tego zjawiska są nowe inwestycje mieszkaniowe na Klinach, os. Gotyk czy starsze osiedle na Wzgórzach Krzesławickich.

Oprócz tej klasyfikacji można także podzielić zespoły nieruchomości ze względu na historię ich powstania. Domyślnie występowanie tego zjawiska dotyczy całkowicie nowych osiedli mieszkaniowych. Jednak ze względu na historię rozwoju Krakowa wiele starszych zespołów odpowiada definicji wyspowego osadnictwa wewnątrz miasta. Często odnosi się to jednak do osad powstałych jeszcze jako całkowicie odrębne byty, dopiero z czasem wchłonięte do miasta wraz z jego rozwojem terytorialnym. Różnica między tymi dwoma typami zazwyczaj opiera się na większej samodzielności zespołów starszych, które powstając, kształtowały i tworzyły obiekty zapewniające ich podstawowe potrzeby. Za przykłady takich zespołów można podać Tyniec, Skotniki oraz Bielany. 


\subsection{OS. ZŁOCIEŃ JAKO MODELOWY PRZYKŁAD WYSPOWEGO OSADNICTWA WEWNĄTRZ MIASTA}

Wzorcowym przykładem wyspowego osadnictwa wewnątrz miasta jest krakowskie os. Złocień. Prezentuje ono typowy dla tego typu jednostek brak powiązań przestrzennych, funkcjonalnych i komunikacyjnych z resztą miasta - jest od niego mocno odizolowane. Chociaż znajduje się w granicach administracyjnych miasta, to jest ono znacząco oddalone od centrum. Otaczają je tereny zdominowane przez przemysł i transport. Jego granice częściowo wyznaczają: droga ekspresowa S7, poprowadzona po wysokim nasypie i estakadzie, a także magistralna linia kolejowa, którą w tym miejscu także częściowo poprowadzono po wysokim nasypie, oraz niewielka rzeka. Poza tym sąsiaduje ono z fabryką, dużą bocznicą kolejową, zakładem napraw i utrzymania taboru kolejowego oraz z terenami trudnodostępnej zieleni nieurządzonej, za którymi znajdują się kolejne, liczne obiekty przemysłowe i magazynowe.

Bardzo silnie odczuwany przez mieszkańców jest brak wyraźnych powiązań komunikacyjnych z centrum miasta, co dotyczy praktycznie wszystkich rodzajów transportu. Do niedawna jedyną drogą dojazdową poprowadzoną do osiedla była ul. Agatowa prowadząca do ul. Półłanki. Nowo otwarta ul. Domagały, chociaż niewątpliwie odciąża ul. Agatową, to podobnie jak ona prowadzi do ul. Półłanki, co skutkuje wyczerpaniem przepustowości obecnego układu drogowego w godzinach szczytu. Dojść do osiedla można przez ul. Domagały, nieposiadającą chodnika ul. Agatową, ścieżkami od strony Brzegów lub pieszym przejściem ze Starego Bieżanowa. Natomiast dedykowanych tras dla rowerzystów nie ma, poza kilkoma ścieżkami wewnątrz fragmentu osiedla.

Bardzo ciekawie wygląda oferta komunikacji zbiorowej. Osiedle to bowiem nie posiada aktualnie żadnego bezpośredniego połączenia ze ścisłym centrum miasta. By do niego dotrzeć, trzeba dostać się autobusem na pętlę tramwajową Mały Płaszów lub Nowy Bieżanów i dopiero stamtąd tramwajem można dotrzeć do centrum. Ze względu na przejazd autobusów w ruchu ogólnym należy spodziewać się znaczących opóźnień w czasie przejazdu, co $\mathrm{w}$ połączeniu z i tak długim rozkładowym czasem jazdy może skutecznie zniechęcać do wyboru tego rodzaju transportu. Na szczęście aktualnie wraz z trwającymi pracami modernizacyjnymi na linii kolejowej w stronę Tarnowa budowana jest stacja, która po wielu latach funkcjonowania tego osiedla zapewni jego mieszkańcom możliwość szybkiego, komfortowego, bezpośredniego i niewrażliwego na korki transportu. 


\subsection{INNE PRZYKŁADY WYSPOWEGO OSADNICTWA WEWNĄTRZ MIASTA}

Za kolejny przykład może posłużyć zespół kilku wysokich budynków mieszkalnych przy ul. bp. Piotra Tomickiego i ul. bp. Filipa Padniewskiego. Jest to zespół zbudowany w Nowej Hucie pomiędzy zakładami Philip Morris, a Łąkami Nowohuckimi. Oprócz nich w bliskim sąsiedztwie znajdziemy jedynie zespół ogródków działkowych. Ciekawe jest to, że tak wyalienowane osiedle znajduje się w odległości, mierzonej w linii prostej, niecałego kilometra od Placu Centralnego i ronda Czyżyńskiego, stanowiących jedne z najważniejszych punktów węzłowych w tej części miasta. Dotrzeć tam można niemal tylko i wyłącznie od al. Jana Pawła II, z której prowadzi do osiedla długi na niemal kilometr sięgacz, rozdzielający się na dwie wymienione wcześniej ulice.

Innym ciekawym przypadkiem są osiedla powstające w okolicy ul. Rydlówka. Jest to atrakcyjna lokalizacja w terenie wyznaczonym przez rzekę Wilgę oraz ulice: Kapelankę, Brożka, Wadowicką i Konopnickiej. Znaczną część tego obszaru zajmują zajezdnia tramwajowa w Podgórzu, okalające ją zakłady i szkoły przemysłowe oraz silnie rozwijająca się od strony ul. Wadowickiej zabudowa biurowo-usługowa. Poza tym znajdują się tu tereny zieleni nieurządzonej wzdłuż rzeki i planowanego kanału ulgi dla Krakowa. Przestrzeń pomiędzy nimi sukcesywnie wypełnia się powstającą zabudową mieszkaniową. Jednocześnie nie znajdziemy tu tak podstawowych placówek jak chociażby szkoła podstawowa czy publiczne przedszkole. Co istotne, jest to teren z ogromnym potencjałem, dobrze zlokalizowany, sąsiadujący ze Starym Podgórzem i os. Podwawelskim, od których oddzielony jest dzisiaj bardzo silnymi, ale równocześnie podatnymi na przekształcenia barierami przestrzenno-funkcjonalnymi. Spójny plan dla tego obszaru, połączony z rewitalizacją terenów przemysłowych, ale także zielonych, mógłby przyczynić się do powstania niezwykle atrakcyjnego i przyjaznego do życia obszaru. Niemniej ważna w tym względzie jest koordynacja działań, tak aby powstająca dziś zabudowa nie zablokowała potencjalnych przekształceń tego obszaru w przyszłości.

Kolejnym intrygującym przypadkiem jest krakowski Pleszów. Nie jest to współczesne osiedle mieszkaniowe, ale osada typu wiejskiego włączona w granice administracyjne Krakowa. Znajduje się tam zabudowa jednorodzinna i zagrodowa skupiona w dużej mierze wokół lokalnego placu i kościoła oraz dobiegających do nich dróg. Niestety nie jest to typowo wiejskie osiedle, bowiem otoczone jest terenami przemysłowymi. Od północy ogranicza je ul. Igołomska, za którą znajduje się kombinat. Po drugiej stronie, od południa, zlokalizowano ogromne składowisko odpadów z tego zakładu przemysłowego oraz osadniki. Należy tu podkreślić, że są one potencjalną bombą ekologiczną ze względu na wysokie stężenia metali ciężkich takich jak rtęć, ołów czy kadm ${ }^{19}$. Natomiast sam teren osiedla z przyległymi do niego terenami zielonymi, w tym rolnymi, znajduje się na obszarze, którego średnica wynosi zaledwie ok. $1 \mathrm{~km}$. 


\section{PODSUMOWANIE}

Analizując dzisiejsze uwarunkowania lokalnego rynku nieruchomości w Krakowie oraz wynikające z nich trendy wśród nabywców i inwestorów, warto zwrócić uwagę na trzy podstawowe zjawiska mogące stanowić zagrożenie dla prawidłowego rozwoju przestrzennego miasta. Należy do nich poszukiwanie wszelkich dostępnych działek na terenach uznawanych za atrakcyjne i ich usilne dogęszczanie kosztem walorów przestrzennych i obszarów zielonych. Ponadto wyraźnie widoczna jest postępująca suburbanizacja, która w połączeniu ze złym planowaniem przestrzennym gmin prowadzi do znaczącego rozproszenia zabudowy okalającej stolicę małopolski. Zauważyć trzeba również trend zdefiniowany przez autora jako „wyspowe osadnictwo wewnątrz miasta”, polegający na powstawaniu enklaw mieszkaniowych pośród terenów przemysłowych lub zielonych-przedmiejskich.

Te zjawiska stanowią oczywistą reakcję rynku na aktualną sytuację i nie należy mieć pretensji do inwestorów ani do nabywców co do ich postępowania, o ile jest ono zgodne z prawem. Ich podstawowy cel to zadbanie o własne interesy i potrzeby, natomiast rolą władz miasta jest wyznaczanie kierunków i planów rozwoju przestrzennego metropolii, które wymuszałoby pewne ograniczenia na podmiotach prywatnych. Interwencja władz samorządowych zdaje się być konieczna, ponieważ trudna sytuacja krakowskiego rynku nieruchomości prowadzi do powstawania coraz bardziej niekorzystnych dla rozwoju Krakowa inwestycji, których skutki będą odczuwalne przez dziesięciolecia, jak nie przez wieki. 

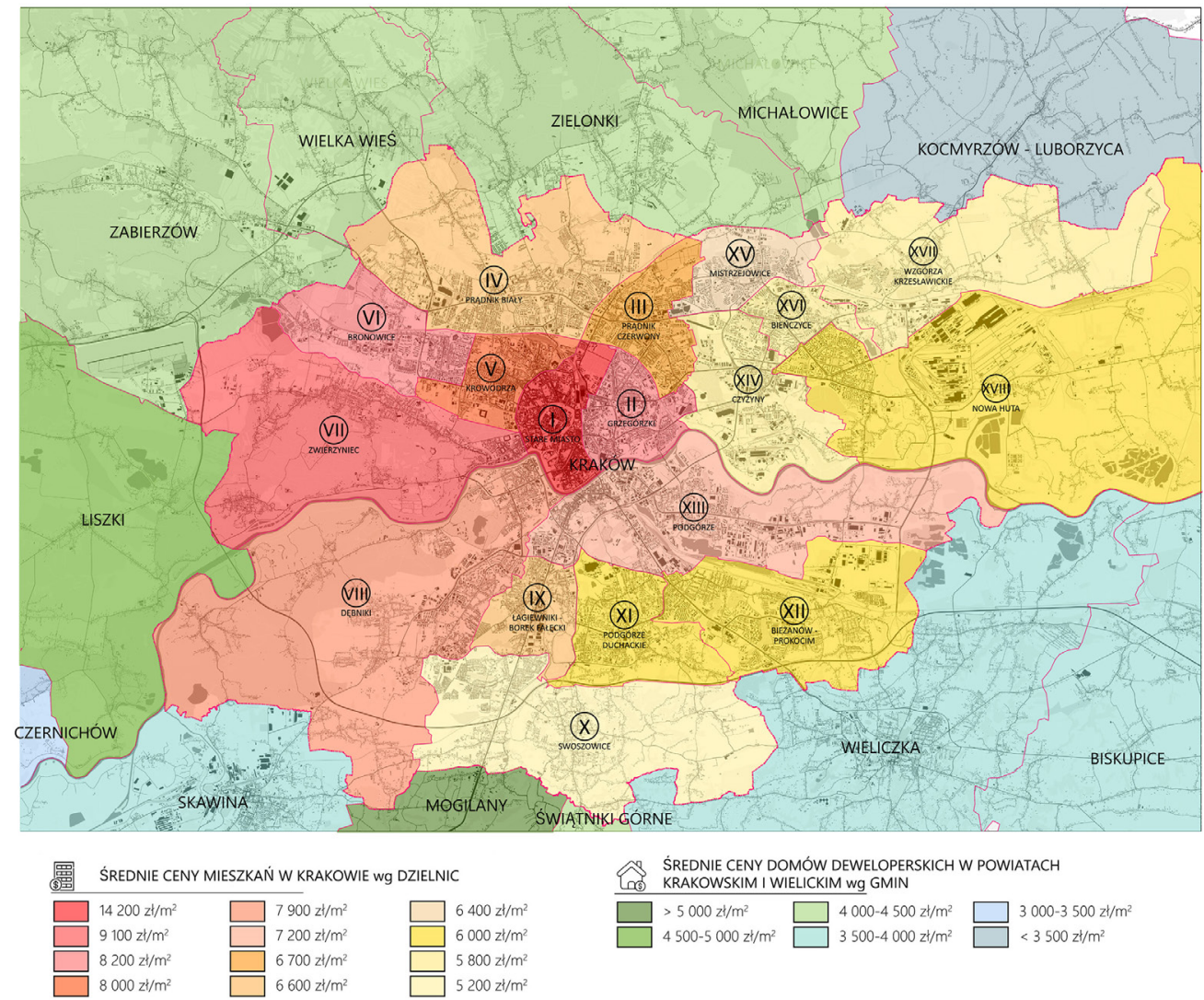

N ŚREDNIE CENY DOMÓW DEWELOPERSKICH W POWIATACH KRAKOWSKIM I WIELICKIM wg GMIN

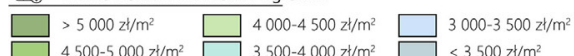
$4500-5000 \mathrm{z} / / \mathrm{m}^{2} \square 3500-4000 \mathrm{z} / \mathrm{m} \mathrm{m}^{2} \square<3500 \mathrm{z} t / \mathrm{m}^{2}$

II. 1. Mapa średnich cen mieszkań na rynku pierwotnym w dzielnicach Krakowa (PLN/m²) (opracowanie własne na podstawie: Krakowski Rynek Nieruchomości 2017, UMK Wydział Rozwoju Miasta, Kraków 2018) 


\section{PRZYPISY}

1 Opracowanie naukowe na podstawie badań do pracy magisterskiej autora: Mistrzejowice-Batowice. Modelowy zespół miejski wg koncepcji TOD w Krakowie, promotor dr inż. arch. Kinga Racoń-Leja, recenzent dr hab. inż. arch. Mateusz Gyurkovich, Wydział Architektury Politechniki Krakowskiej, Kraków 2019.

2 Krakowski Rynek Nieruchomości 2017, UMK Wydział Rozwoju Miasta, Kraków 2018, s. 30.

3 Internetowy portal statystyczny Polska w liczbach, http://www.polskawliczbach.pl/ Krakow\#nieruchomo\%C5\%9Bci.

4 Bank Danych Lokalnych, GUS, https://bdl.stat.gov.pl/BDL/dane/teryt/kategoria/1787.

5 Krakowski Rynek..., op. cit., s. 46.

6 Ibidem, s. 27.

7 Ibidem, s. 29.

8 Ibidem, s. 29-30.

9 Ibidem.

10 Ibidem, s. 27.

11 P. Ogórek, Kraków. Deweloper wciska się na podwórko. Fragmenty Krowodrzy zagrożone zabudowq, Gazeta Krakowska, https://gazetakrakowska.pl/krakow-deweloper-wciska-siena-podworko-fragmenty-krowodrzy-zagrozone-zabudowa/ar/c9-14298225.

12 B. Dybała, Młynówce Królewskiej znów grozi zabudowa. Choć miało być zielono, Gazeta Krakowska, https://gazetakrakowska.pl/mlynowce-krolewskiej-znow-grozi-zabudowa-chocmialo-byc-zielono/ar/c1-14352139.

13 Krakowski Rynek..., op. cit., s. 29-30, 57.

${ }^{14}$ P. Śleszyński i in., Analiza stanu i uwarunkowań prac planistycznych w gminach w 2017 roku, IGiPZ PAN, Warszawa 2018, s. 14.

${ }^{15}$ NIK o systemie gospodarowania przestrzeniq gminy jako dobrem publicznym [analiza NIK], Oficjalny Portal Najwyższej Izby Kontroli, https://www.nik.gov.pl/aktualnosci/nik-osystemie-gospodarowania-przestrzenia-gmin.html.

16 P. Śleszyński i in., op. cit.

17 Oficjalny portal gminy Michałowice, https://www.michalowice.malopolska.pl/gmina/ solectwa/michalowice.

18 J. Orszulak, W gminach wokół Krakowa wciq̨ż wolno idzie wymiana pieców, Radio Kraków, https://www.radiokrakow.pl/wiadomosci/krakow/w-gminach-wokol-krakowa-wciaz-wolno-idzie-wymiana-piecow/.

19 P. Błaszczyk, Metale ciężkie na składowisku z odpadami z huty. Znajduje się tam $6 \mathrm{~m} / \mathrm{n}$ ton nieczystości, RMF24.pl, https://www.rmf24.pl/fakty/polska/news-metale-ciezkie-naskladowisku-z-odpadami-z-huty-znajduje-sie,nld,2611597. 


\section{BIBLIOGRAFIA}

Bank Danych Lokalnych, GUS, [online] https://bdl.stat.gov.pl/BDL/dane/teryt/kategoria/1787 (dostęp: 20.06.2019).

Bieda K., Transport jako czynnik zrównoważonego rozwoju Krakowa, Czasopismo Techniczne, 3-A/2011, 7-23.

Błaszczyk P., Metale ciężkie na składowisku z odpadami z huty. Znajduje się tam $6 \mathrm{mln}$ ton nieczystości, RMF24.pl, [online] https://www.rmf24.pl/fakty/polska/news-metale-ciezkie-na-skladowisku-z-odpadami-z-huty-znajduje-sie,nld,2611597 (dostęp: 14.11.2019).

Dąbrowska-Milewska G., Czy w Polsce potrzebne sq krajowe standardy urbanistyczne dla terenów mieszkaniowych?, Architecturae et Artibus, 1/2010, 12-16.

Dybała B., Młynówce Królewskiej znów grozi zabudowa. Choć miało być zielono, Gazeta Krakowska, [online] https://gazetakrakowska.pl/mlynowce-krolewskiej-znow-grozi-zabudowa-choc-mialo-byc-zielono/ar/c1-14352139 (dostęp: 14.11.2019).

Gyurkovich M., Mieszkać przy miejskiej przestrzeni publicznej, Czasopismo Techniczne, 2-A/2010, 145-153.

Kantarek A., Tranzyt a spójność formy miasta, Czasopismo Techniczne, 1-A/2010, 65-74.

Krakowski Rynek Nieruchomości 2017, UMK Wydział Rozwoju Miasta, Kraków 2018.

NIK o systemie gospodarowania przestrzeniq gminy jako dobrem publicznym [analiza NIK], Oficjalny Portal Najwyższej Izby Kontroli, [online] https://www.nik.gov.pl/aktualnosci/ nik-o-systemie-gospodarowania-przestrzenia-gmin.html (dostęp: 14.11.2019).

Oficjalny portal gminy Michałowice, [online] https://www.michalowice.malopolska.pl/gmina/ solectwa/michalowice (dostęp: 14.11.2019).

Ogórek P., Kraków. Deweloper wciska się na podwórko. Fragmenty Krowodrzy zagrożone zabudowq, Gazeta Krakowska, [online] https://gazetakrakowska.pl/krakow-deweloper-wciska-sie-na-podworko-fragmenty-krowodrzy-zagrozone-zabudowa/ar/c9-14298225 (dostęp: 14.11.2019).

Orszulak J., W gminach wokół Krakowa wciq̨ż wolno idzie wymiana pieców, Radio Kraków, [online] https://www.radiokrakow.pl/wiadomosci/krakow/w-gminach-wokol-krakowa-wciaz-wolno-idzie-wymiana-piecow/ (dostęp: 23.04.2019).

Polska w liczbach, [online] http://www.polskawliczbach.pl/Krakow\#nieruchomo\%C5\%9Bci (dostęp: 20.06.2019).

Racoń-Leja K., Bariery w kształtowaniu przestrzeni publicznej w zespołach mieszkaniowych, Czasopismo Techniczne, 3-A/2010, 165-170.

Racoń-Leja K., Osiedle przyszłości wobec prognozowanych zmian demograficznych, Środowisko Mieszkaniowe/Housing Environment, 12/2013, 99-103.

Spyrka W., Planowanie korytarzy osiedleńczych w oparciu o sieć transportu zbiorowego przykład pasma Doliny Raby, praca doktorska, Kraków 2017. 
Suchorzewski W., Rola transportu w kształtowaniu struktury funkcjonalno-przestrzennej miast, Czasopismo Techniczne, 1-A/2010, 32-44.

Śleszyński P. i in., Analiza stanu i uwarunkowań prac planistycznych w gminach w 2017 roku, IGiPZ PAN, Warszawa 2018. 